\title{
Mechanical properties of alkali activated geopolymer paste using different Romanian fly ash sources - experimental results
}

\author{
Adrian Lăzărescu ${ }^{1,2, *}$, Călin Mircea $^{2}$, Henriette Szilagyi ${ }^{1}$, and Cornelia Baeră $^{3}$ \\ ${ }^{1}$ NIRD URBAN-INCERC, Cluj-Napoca Branch, 400524 Calea Florești 117, Cluj-Napoca, Romania \\ ${ }^{2}$ Technical University of Cluj-Napoca, Civil Engineering Faculty, 400020 Daicoviciu 15, Cluj-Napoca, Romania \\ ${ }^{3}$ NIRD URBAN-INCERC, Timişoara Branch, 300223 Traian Lalescu 2, Timișoara, Romania
}

\begin{abstract}
As concrete demand is constantly increasing in recent years and also considering that cement production is both a consumer of natural resources and a source of carbon dioxide release into the atmosphere, there have been worldwide investigations into green alternatives for making concrete environmentally friendlier and simultaneously to satisfy the development of infrastructure facilities. The use of fly ash as a component of cementitious binders is not new but when considering the specific case of alkaline activation and fly ash representing the only source for the binder formation, it necessitates a more complete understanding of its specific reactions during the alkaline activation process. Since the fly ash varies dramatically, not only from one source to another, but also from one batch to another even when provided by the same power plant, its chemistry in obtaining alkali-activated materials during the geopolymerisation process and the final mechanical properties are considered crucial for the performance of geopolymer concrete. This paper will provide a review of the experimental results concerning the physical and mechanical evaluation of the alkali-activated fly ash-based geopolymer materials, developed with different types of fly ash, for a better understanding of geopolymer concrete production control.
\end{abstract}

\section{Introduction}

Concrete is the second most widely used material in the world, being considered the most versatile, durable and reliable building material - therefore the need to produce large quantities of Portland cement (PC) as binder for concrete are constantly increasing. The cement industry is considered to be the second highest carbon dioxide generator, being preceded only by the automotive industry. Each tonne of produced cement requires between 60 and $130 \mathrm{~kg}$ of liquid fuel or its equivalent, depending on the type of cement and the manufacturing process used, and approximately $110 \mathrm{KWh}$ of electricity [1]. One tonne of produced cement releases between 0.8 and 1.1 tonnes of $\mathrm{CO}_{2}$ into the atmosphere, as a subsequent consequence of combustion and calcareous calcination [2]. Only in 2014, the world cement production represented approximately 4.2 billion tonnes [3], indicating an obvious increase related to the previous years.

Environmental problems associated with ordinary Portland cement production are extremely well known and they represent a problem which is carefully monitored, in terms of the amount of carbon dioxide released into the atmosphere during its production. Constant efforts are therefore made in order to counteract this effect in future years. As the industry is constantly growing, the involvement of modern building materials in the economic world is more than necessary. Alkaline activation of the fly ash represents a special procedure, able to generate the solidification of fly ash powder when mixing it with a certain type of alkaline activator and creating a new binding material. Consequently, it has opened the perspective of obtaining a new building material when incorporating aggregates, as an alternative to traditional concrete and cementbased composites [4-7]. Developing these types of composites, with similar or even superior, properties to cementitious composites, without using cement in the composition, creates an extraordinary opportunity for the environment and for the construction industry, constituting itself as an alternative to traditional technology, both due to mechanical properties and high resistance in aggressive environments [8].

The large amount of fly ash resulting from the energy industry in Romania can create new opportunities to use this waste as a substitute for Portland cement in the production of new materials. In 2017 only, one power plant in Romania produced nearly 650,000 tonnes of fly ash, 50,000 tonnes of slag and 50,000 tonnes of gypsum. Despite the slag recovery by recycling means its reuse into the coal supply of boilers $(43,000 \mathrm{t} / \mathrm{year})$ and the fly ash delivery to the construction industry (cement, concrete, mortar for stabilizing soils, roads etc.), representing approximately $162,000 \mathrm{t} /$ year, the unused

* Corresponding author: adrian,lazarescu@ incerc-cluj.ro 
quantity of fly ash from the power plant is still an important environmental problem, with almost 565,000 t/year stored in waste dumps [9].

When fly ash is used as a main binding material in the production of alkali activated materials, a careful consideration is needed when choosing the primary materials used for the mix. Chemical properties of the components have to be taken into consideration so that the geopolymerisation reaction can properly occur [10]. The solid part (fly ash) and the liquid part (alkaline activator) in the system should not be considered as additions, as they represent the main constituents of the binder [11].

The physical, chemical and mechanical properties of the alkali-activated geopolymer materials are strongly influenced by the properties of raw material such as fly ash $[12,13]$. Since the properties of fly ash vary, depending on several parameters (the quality of coal, temperature and process of combustion etc.) [12-15], understanding the mechanisms that generate the geopolymerisation process have to be well known.

The aim of this paper is to present the preliminary results obtained on alkali-activated fly ash-based geopolymer paste using different Romanian power-plant source materials for producing this type of material, based on efficient source materials, available at national level and also presenting the effect of their physical and chemical properties on the compressive strength of the binder.

\section{Experimental method - materials and methods}

This chapter summarizes both the state-of-the art information about the raw components used for the development of alkali-activated fly ash-based geopolymer pastes (FAGP) and also about the applied particular experimental methodology (mix design, moulding methods, curing and also testing methods).

\subsection{Materials}

\subsubsection{Fly ash}

Fly ash (FA) is a by-product obtained by electrostatic or mechanical precipitation of the pulverized particles resulting from the coal-fired combustion gases of the furnaces in power plants. It is a fine powder, consisting mainly of spherical shaped glass particles [16, 17]. Although some certain characteristics proved to be common for all fly ash types, due to factors like coal type as raw material for FA production and the burning process as well, fly ash powders show significant differences when coming to their chemical composition. The raised variation of the chemical composition, leading to different performance of FA as binding material, when used as primary raw material for producing alkali-activated fly ash-based binding paste (FAGPP), represents an essential aspect for the general development of the concept [18].
For the current research, Class F fly ash was used for preparing the FAGPP specimens and was characterized as follows [19]: $\mathrm{SiO}_{2}+\mathrm{Al}_{2} \mathrm{O}_{3}+\mathrm{Fe}_{2} \mathrm{O}_{3}>70 \%, \mathrm{SO}_{3}<5 \%$ and L.O.I. $<6 \%$.

Two different Romanian power plant, low-calcium, fly ashes (FA.S1 and FA.S2) were used in this study (Fig. 1a and Fig. 1b), focused on the development and implicitly, the comparative analyses of FAGPP mechanical properties [20]. The chemical composition of the FA samples was established by X-ray fluorescence analysis (XRF analysis), presented in Table 1. Also their relevant physical properties are presented in Table 2 .

a)
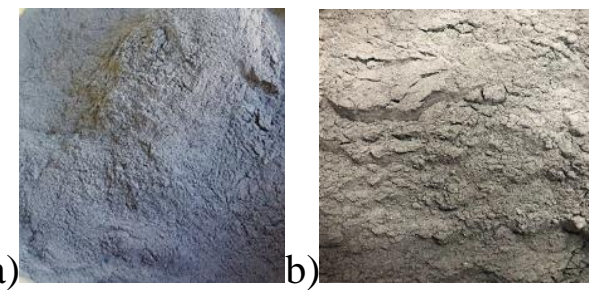

Fig. 1. a) FA.S1 sample b) FA.S2 sample

Table 1. XRF analysis data for the fly ash samples.

\begin{tabular}{|c|c|c|}
\hline Oxides & $\begin{array}{c}\text { FA.S1 } \\
\text { \% }\end{array}$ & $\begin{array}{c}\text { FA.S2 } \\
\text { \% }\end{array}$ \\
\hline $\mathrm{SiO}_{2}$ & 53.61 & 54.32 \\
\hline $\mathrm{Al}_{2} \mathrm{O}_{3}$ & 26.16 & 22.04 \\
\hline $\mathrm{Fe}_{2} \mathrm{O}_{3}$ & 7.58 & 9.02 \\
\hline $\mathrm{CaO}$ & 2.42 & 5.85 \\
\hline $\mathrm{MgO}$ & 1,49 & 2,48 \\
\hline $\mathrm{SO} 3$ & 0.26 & 0.20 \\
\hline $\mathrm{Na}_{2} \mathrm{O}$ & 0.59 & 0.54 \\
\hline $\mathrm{P}_{2} \mathrm{O}_{5}$ & 0,12 & 0,16 \\
\hline $\mathrm{TiO}_{2}$ & 1.04 & 0.86 \\
\hline $\mathrm{Mn}_{2} \mathrm{O}_{3}$ & 0,08 & 0.06 \\
\hline $\mathrm{L} . \mathrm{O} . \mathrm{I}$. & 3.57 & 3.05 \\
\hline
\end{tabular}

Table 2. Physical properties of fly ash samples

\begin{tabular}{|c|c|c|}
\hline Properties & FA.S1 & FA.S2 \\
\hline Colour & Light grey & Greyish white \\
\hline $\begin{array}{c}\text { Residue retained } \\
\text { on } 45 \mu \mathrm{m}, \%\end{array}$ & 37.6 & 59.4 \\
\hline
\end{tabular}




\subsubsection{Alkaline Activator}

When in contact, the reactive solids from the fly ash and the alkaline solution react and a hard, water-resistant material is generated due to the formation of an alumino-silicate network [21] and geopolymerisation occurs, resulting from the dissolution of the $\mathrm{Si}$ and $\mathrm{Al}$ compounds of the fly ash [22].

By using an alkaline hydroxide activating solution and a silicate solution, the $\mathrm{SiO}_{2} / \mathrm{Al}_{2} \mathrm{O}_{3}$ and $\mathrm{Na}_{2} \mathrm{O} / \mathrm{SiO}_{2}$ ratios in the mixture are optimized to obtain higher mechanical performances $[23,24]$.

The most commonly used combination for the production of the alkaline activator is sodium hydroxide $(\mathrm{NaOH})$ or potassium hydroxide $(\mathrm{KOH})$, together with a sodium silicate solution $\left(\mathrm{nSiO}_{2} \mathrm{Na}_{2} \mathrm{O}\right)$ or a potassium silicate solution $\left(\mathrm{nSiO}_{2} \mathrm{~K}_{2} \mathrm{O}\right)$ [25]. Waterglass adds silicon atoms and mixed liquid, both of which play an important role in producing the geopolymerisation process.

It is recommended to use sodium hydroxide of purity ranging between 94 and $99 \%$. Regarding the sodium hydroxide solution, it should be prepared 24 hours before use, but not earlier than 36 hours because it loses its properties as an activator [26]. Sodium hydroxide concentration has an important influence on the final mechanical properties of the alkali-activated fly ash-based geopolymer material [27, 28].

The alkaline activator used for this experimental study was a combination of sodium hydroxide solution $(\mathrm{NaOH})$ and sodium silicate solution $\left(\mathrm{Na}_{2} \mathrm{SiO}_{3}\right)$, as shown in Fig. 2a and Fig. 2b. The sodium silicate solution was purchased from the local market and its chemical composition was $\mathrm{SiO}_{2}=30 \%$, $\mathrm{Na}_{2} \mathrm{O}=14 \%$ and $\mathrm{H}_{2} \mathrm{O}=56 \%$. The sodium hydroxide solution was prepared by dissolving the $\mathrm{NaOH}$ flakes into water until the desired concentration of the solution was achieved. Two distinct $\mathrm{NaOH}$ solutions, of $10 \mathrm{M}$ and $12 \mathrm{M}$ respectively, were prepared for FAGPP mixes. The $10 \mathrm{M} \mathrm{NaOH}$ solution was prepared by dissolving $400 \mathrm{~g}$ of $\mathrm{NaOH}$ flakes into water for 1 litre solution $(40 \mathrm{~g} \times 10=400 \mathrm{~g} \mathrm{NaOH} /$ litre, where $40 \mathrm{~g}$ is the molecular weight of $\mathrm{NaOH}$ ) [20].
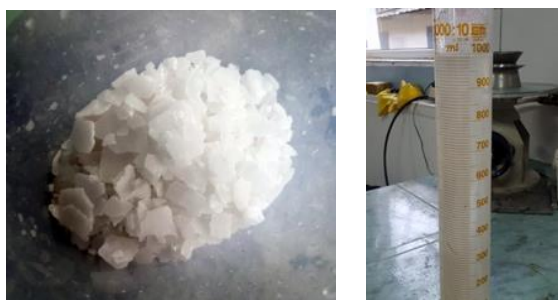

Fig. 2. a) $\mathrm{NaOH}$ flakes b) $\mathrm{Na}_{2} \mathrm{SiO}_{3}$ solution

\subsection{Mix design of FAGPP}

Producing FAGPP does not imply a different technology than in the case of conventional mortars, the use of a pallet mixer is convenient for a proper mix. Preliminary results obtained on FAGPP, when using Romanian local raw materials, indicated that an alkaline activator/fly ash ratio (AA/FA) of 0.5 for FA.S1 and 1.0 for FA.S2 of fly ash provided good workability [29]. The $\mathrm{Na}_{2} \mathrm{SiO}_{3} / \mathrm{NaOH}$ solution ratios ranged between 0.5 and 2.5 , for a comparative analysis regarding the variation effect on the material behaviour. Table 3 summarizes the fly ashbased geopolymer paste mixes developed in the current experimental work.

The FA and AA were mixed together for three minutes, until a homogeneous paste was obtained. The mixtures were then placed in $40 \mathrm{~mm} \times 40 \mathrm{~mm} \times 160 \mathrm{~mm}$ moulds and heat cured at $70^{\circ} \mathrm{C}$ for 24 hours. A glass film was placed on top of every mould in order to prevent excessive water release from the mixtures. After demoulding, the FAGPP specimens were stored in the climatic chamber at the temperature $\mathrm{T}(20 \pm 1)^{\circ} \mathrm{C}$ and relative humidity $\mathrm{RH}(60 \pm 5) \%$ until the age of 7 days, when their mechanical performance was tested. Fig. 3 shows aspects related to the preparation of the FAGPP samples.

Table 3. Mix design of FAGPP.

\begin{tabular}{|c|c|c|c|}
\hline FA type & $\begin{array}{c}\mathbf{A A} / \mathbf{F A} \\
\text { ratio }\end{array}$ & $\begin{array}{c}\mathrm{Na}_{2} \mathrm{SiO}_{3} / \\
\mathrm{NaOH} \text { ratio }\end{array}$ & $\begin{array}{c}\mathrm{NaOH} \\
\text { molarity }\end{array}$ \\
\hline \multirow{3}{*}{ FA.S1 } & \multirow{3}{*}{0.5} & 0.5 & \multirow{5}{*}{$\begin{array}{l}10 \mathrm{M} \\
\text { and } \\
12 \mathrm{M}\end{array}$} \\
\hline & & 1.0 & \\
\hline & & 1.5 & \\
\hline \multirow[t]{2}{*}{ FA.S2 } & \multirow[t]{2}{*}{1.0} & 2.0 & \\
\hline & & 2.5 & \\
\hline
\end{tabular}
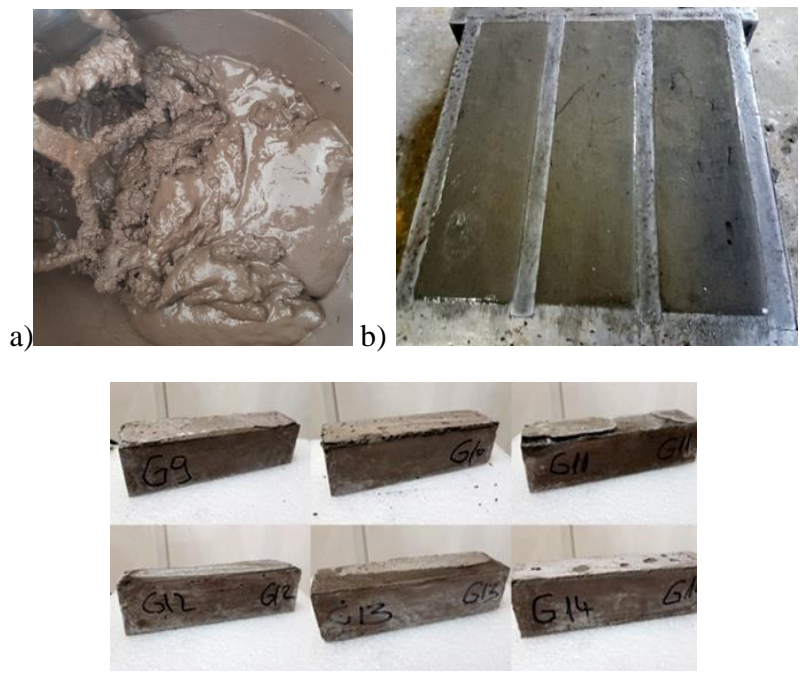

Fig. 3. a) Final mixing sequence b) Moulding c) FAGPP specimens after de-moulding

\subsection{Testing method of FAGPP samples}

The FAGPP compressive strength testing (as shown in Fig. 4) was performed at the age of 7 days, using three prismatic specimens for each type of alkali-activated fly ash-based geopolymer paste; the mean value of the results was considered relevant for the data interpretation. The testing method was in accordance to EN 196-1:2006, namely the standard testing methodology for ordinary Cement mortars. Early age testing at 7 days was considered relevant for the comparative evaluation, as previously experiments proved that generally the FAGPP reach most of their compressive potential by this age [20]. 


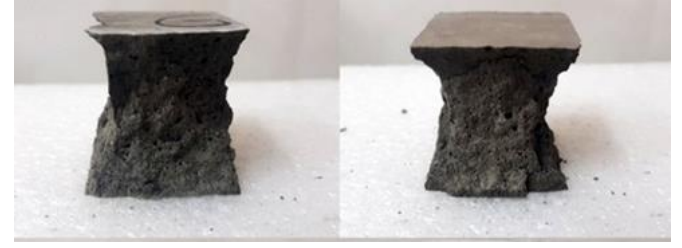

Fig. 4. FAGPP samples after compressive test

\section{Results and discussions}

Alkali-activated fly ash-based geopolymer materials properties can be notably influenced by several important factors such as the source and quality of the fly ash used as the precursor material, the $\mathrm{NaOH}$ solution concentration and the $\mathrm{Na}_{2} \mathrm{SiO}_{3} / \mathrm{NaOH}$ solution ratio. The physical and chemical properties of the fly ash samples, as well as the different ratios of alkaline liquid ratios, at the age of 7 days, and FAGPP compressive strength were consider relevant for the comparative evaluation of the above nominated parameters.

\subsection{Fly ash parameters}

The oxide composition of the two samples of fly ash were analysed by XRF analysis and are listed in Table 1. Based on literature [30], both samples of fly ash are categorized as Class $\mathrm{F}$ fly ash, because the amount of $\mathrm{SiO}_{2}, \mathrm{Al}_{2} \mathrm{O}_{3}$ and $\mathrm{Fe}_{2} \mathrm{O}_{3}$ is more than $70 \%$ (Table 4). A high difference occurs in $\mathrm{CaO}$ content, where FA.S2 has a higher percentage than FA.S1. The literature suggests [31] that a low content of $\mathrm{CaO}$ in the chemical composition of the fly ash leads to better compressive strength of the material.

Table 4. Class F compliance of the FA samples.

\begin{tabular}{|c|c|}
\hline FA & $\begin{array}{c}\mathbf{S i O}_{2}+\mathbf{A l}_{2} \mathbf{O}_{\mathbf{3}}+\mathrm{Fe}_{2} \mathbf{O}_{\mathbf{3}} \\
\text { FA.S1 }\end{array}$ \\
\hline FA.S2 & 87.35 \\
\hline
\end{tabular}

The reactivity of fly ash samples highly depends on the LOI, which represents the unburned material [31, 32]. Both samples of fly ash have LOI less than $6 \%$, as recommended by standards [30] and also less than $5 \%$, as recommended by literature [31]. The fineness of the fly ash is defined as the percentage of particles retained on the $45 \mu \mathrm{m}$ mesh sieve. As shown in Table 2, FA.S1 has a lower percentage of retained particles on the mesh sieve $(37.6 \%)$, therefore it has a higher fineness.

Although the chemical composition and the L.O.I. parameters of the fly ash samples used (FA.S1 and FA.S2) are only slightly different, as shown in Table 1, it can be easily noticed (Table 3 ) that the FAGPP mix design for each FA sample is significantly different. In order to achieve the desired workability and to obtain a proper geopolymerisation process, the alkaline activator/fly ash ratio for FA.S1 was 0.5 and for FA.S2 was 1.0. The FAGPP samples prepared with FA.S2 showed lower compressive strength values for all the $\mathrm{Na}_{2} \mathrm{SiO}_{3} / \mathrm{NaOH}$ ratios and for both, $10 \mathrm{M}$ and $12 \mathrm{M} \mathrm{NaOH}$ solution concentration. the fineness of the two fly ash samples being different (Table 2), shows that this parameter plays an important role in the workability of the mix and further on, in the compressive strength development of the alkali activated material (Fig. 5 and Fig. 6): - the finer the fly ash, the better the workability of the mix, therefore, a lower alkaline activator/fly ash ratio.

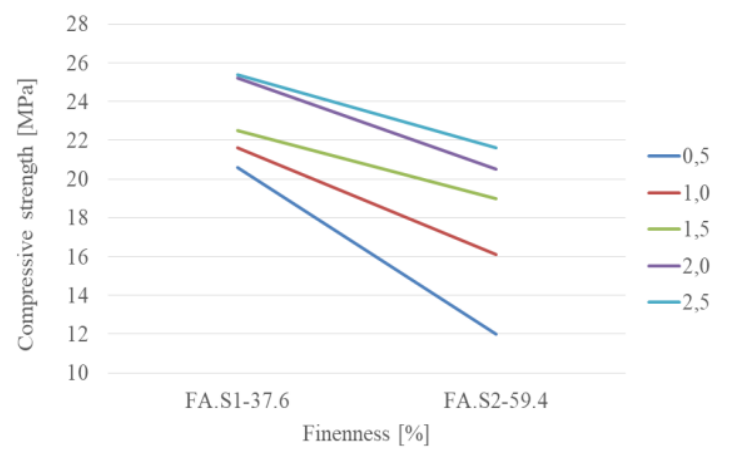

Fig. 5. Effect of fineness to compressive strength $(10 \mathrm{M} \mathrm{NaOH}$ solution -0.5 to 2,5 alkaline activator ratio)

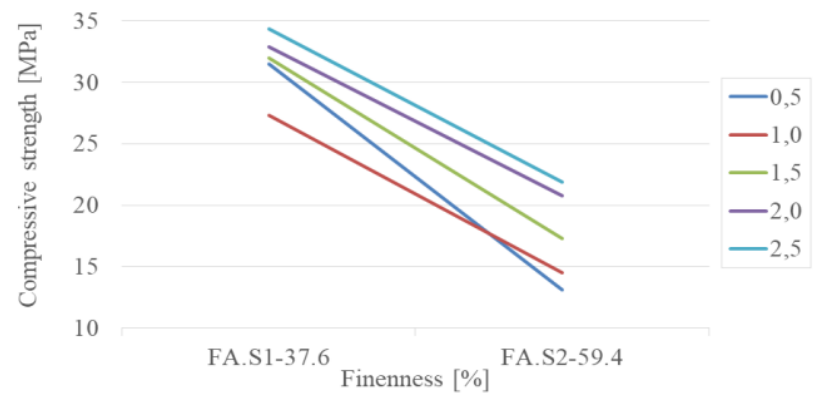

Fig. 6. Effect of fineness to compressive strength $(12 \mathrm{M} \mathrm{NaOH}$ solution -0.5 to 2.5 alkaline activator ratio)

The influence of fly ash fineness (in terms of particles retained on the $45 \mu \mathrm{m}$ sieve) on the compressive strength is graphically emphasised in the figures above. The graphs indicate that the compressive strength decreases as the percentage of particles retained on the $45 \mu \mathrm{m}$ sieve increases, therefore the fly ash sample with a lower fineness generates lower compressive strength values. A low percentage of particle fly ash retained on the sieve shows higher specific surface area, therefore a higher reactivity of the fly ash and subsequently, an increase in the compressive strength of the FAGPP.

The decrease in the amount of fly ash retained on the $45 \mu \mathrm{m}$ sieve causes a decrease of the final pore size of the binder and also of the total porosity, with an increase of the density of the material and, therefore, a higher final compressive strength. This happens because fly ash is more reactive as smaller particles, compared to bigger ones, in its physical composition $[33,34,35]$. 


\subsection{Influence of the $\mathrm{Na}_{2} \mathrm{SiO}_{3} / \mathrm{NaOH}$ ratio and the $\mathrm{NaOH}$ solution concentration on the compressive strength}

The effect of sodium silicate solution to sodium hydroxide solution $\left(\mathrm{Na}_{2} \mathrm{SiO}_{3} / \mathrm{NaOH}\right.$ ratio), by mass, on the compressive strength of the FAGPPs specimens has been observed by analysing it for each of the molar concentrations of sodium hydroxide solution and for each fly ash sample, FA.S1 and FA.S2. The results are graphically presented in Fig. 7 and Fig. 8, both proving that the best compressive values were obtained for the $\mathrm{Na}_{2} \mathrm{SiO}_{3} / \mathrm{NaOH}$ ratio of 2.5 (for both samples of fly ash). For the mixtures prepared using FA.S1, the ratios that induced lower compressive strength were generally generated by a lower geopolymerisation reaction during the mixing of the components. The compressive strength evolution strongly depends the complexity of the geopolymerisation reaction and the concentration of the alkaline activator constituents.

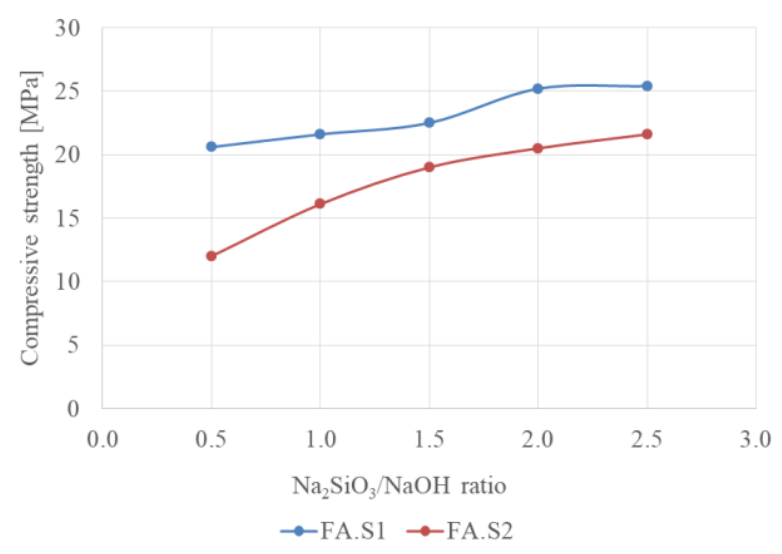

Fig. 7. Effect of $\mathrm{Na}_{2} \mathrm{SiO}_{3} / \mathrm{NaOH}$ ratio on the compressive strength (10M NaOH solution)

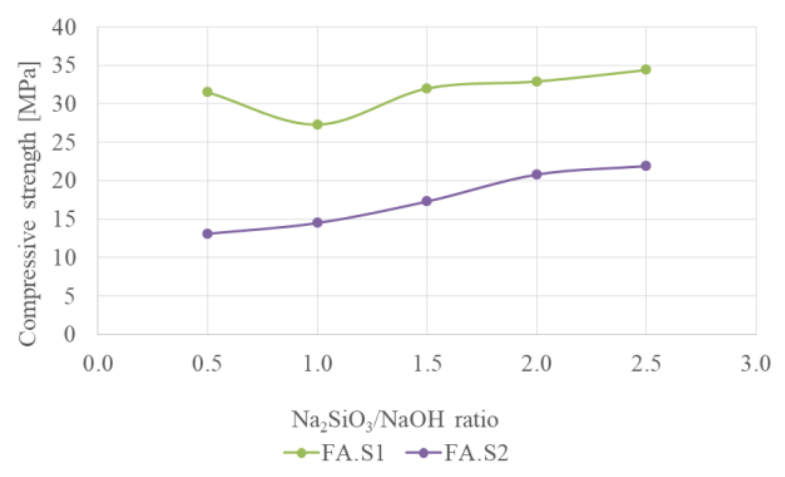

Fig. 8. Effect of $\mathrm{Na}_{2} \mathrm{SiO}_{3} / \mathrm{NaOH}$ ratio on the compressive strength (12M NaOH solution)

Fig. 7 and Fig. 8 also illustrate the effect of $\mathrm{NaOH}$ solution concentration on the compressive strength of the FAGPP specimens. The compressive strength of the geopolymer binder increases with the increase in the concentration of the $\mathrm{NaOH}$ solution and is also significantly affecting the microstructure of the alkaliactivated geopolymer binder in terms of geopolymer synthesis [20]. A higher concentration of sodium hydroxide solution leads to a greater dissolution of precursor (fly ash), hence a higher compressive strength is achieved.

\section{Summary and conclusions}

The experimental procedures for obtaining FAGPP, using Romanian local raw materials, were performed in controlled laboratory conditions, regarding the temperature, the relative humidity, the pressure and the air flow velocity, in order to collect proper data that could be used for future studies in the topic. Careful investigation of specific ratio variations within the paste when using fly ash from different sources provided important conclusions regarding further approaches of the mix design of the geopolymer material. Optimal dosage of the geopolymer paste for superior compressive performance will be used in geopolymer mortar and concrete design.

The best results were provided by the alkali-activated FAGPP when using FA.S1, on mixes developed by using the $2.5 \mathrm{Na}_{2} \mathrm{SiO}_{3} / \mathrm{NaOH}$ solution ratio and $10 \mathrm{M} \mathrm{NaOH}$ concentration: $25.4 \mathrm{MPa}$, respectively $12 \mathrm{M} \mathrm{NaOH}$ concentration: $34.4 \mathrm{MPa}$.

Fly ash FA.S1 provided both proper workability of the mixes and better compressive strength of the material. The compressive strength of the FAGPP increased with the decrease of the percentage of particles of the fly ash retained on the $45 \mu \mathrm{m}$ sieve. The compressive strength of the geopolymer paste was influenced by both the physical and chemical characteristics of fly ash, however, the compressive strength was more affected by the fineness of the fly ash. Also, the compressive strength of the FAGPP samples increased with the increase of the molar concentration of the $\mathrm{NaOH}$ solution molarity.

The results obtained on FAGPP specimens contribute to the necessity of ongoing research on the identification and exploitation of the various Romanian sources of byproducts, resulting both from secondary materials and wastes, from technological processes in various industries. Besides the economic advantages, an important aspect is the ecological one, namely the re-use of industrial wastes and by-products (sources of environmental pollution) into the economic circuit. Likewise, total replacement of cement in innovative, smart materials strongly contributes to the reduction of carbon dioxide emissions.

Further similar studies will be performed using different types of fly ash, from different Romanian power-plants, for a stronger confirmation of the present conclusion. The influence of fly ash chemical composition on geopolymer paste matrix, with respect to the evaluated $\mathrm{NaOH}$ concentration and the $\mathrm{Na}_{2} \mathrm{SiO}_{3} / \mathrm{NaOH}$ solution ratio and the optimization of the mix design, represent the near future challenges of the ongoing research.

\section{Acknowledgements}

The current experimental program was carried out in the framework of the $\mathrm{PhD}$. Research Program of the first 
author at the Technical University of Cluj-Napoca. All the experimental work has been carried out in the laboratory of NIRD. URBAN-INCERC, Cluj-Napoca Branch, Romania and was supported by the Research Programmes for Smart Specialization, Sustainable Territorial Development, Environment Preservation and Resilience of Building Heritage - "CONCRET", PN 18 3504 03: "Research for valorising the inert, hydraulic late or pozzolanic mineral additions in innovative cementitious materials for resilient structures, in the context of implementing the "Circular Economy" concepts in Romania and PN 193304 02: "Sustainable solutions to ensure health and safety of the population in the open innovation context and environmental protection", financed by the Romanian Government.

\section{References}

1. V.M. Malhotra, Role of supplementary cementing materials in reducing greenhouse gas emissions. Infrastructure regeneration and rehabilitation improving the quality of life through better construction: a vision for the next millennium, Sheffield (1999)

2. International Energy Agency, Carbon emissions reductions up to 2050, Cement Technology Roadmap (2009)

3. CEMBUREAU: World Statistical Report Edition (2017)

4. J. Davidovits, Synthesis of new high-temperature Geopolymers for reinforced plastics and composites, SPE PACTE'79, Costa Mesa, California, Society of Plastics Engineers, USA (1979), pp. 151-154

5. J. Davidovits, Chemistry of Geopolymeric Systems. Terminology, International Conference on Geopolymer Concrete, France (1999)

6. J. Davidovits, High-Alkali Cements for $21^{\text {st }}$ Century Concretes, in Concrete Technology, Past, Present and Future, Proceedings of V. Mohan Malhotra Symposium, Ed.: P. Kumar Mehta, ACI 144 (2003), pp. 383-387

7. A. Palomo, M.W. Grutzeck, M.T. Blanco, AlkaliActivated Fly Ashes: A Cement for the Future, Cem. Con. Res. 29 (1999) 8, pp. 1323-1329

8. P. Duxon, J.L. Provis, G.C. Luley, J.S.J. van Deventer, The role of inorganic polymer technology in the development of 'green concrete', Cem. Con. Res. 37 (2007), pp. 1590-1597

9. NIRD URBAN-INCERC, Research for valorising the inert, hydraulic late or pozzolanic mineral additions in innovative cementitious materials for resilient structures, in the context of implementing the 'circular economy' concepts in Romania, National Programme 183504 03, Ministry of Research and Innovation, Romania (2018)

10. A. Bilodeau, V.M. Malhotra, High-volume fly ash system: Concrete solution for sustainable development, ACI Mater. J. 97 (2000) 1, pp. 41-48
11.J.L. Provis, J.S.J. van Deventer, Alkali Activated Materials, State-of-the-Art Report, RILEM 224AAN (2001)

12. J. van Jaarsveld, J. van Deventer, G. Lukey, The characterisation of source materials in fly ash-based geopolymers, Mater. Lett. 57 (2003), pp. 1272-1280

13. E.I. Diaz, E.N. Allouche, S. Eklund, Factors affecting the suitability of fly ash as source material for geopolymers, Fuel 89 (2010), pp 992-996

14.P. Chindaprasirt, U. Rattanasak, Utilisation of blended fluidized bed combustion (FBC) ash and pulverized coal combustion (PCC) fly ash in geopolymer, Waste Management 30 (2011), pp. 667672

15. P. Chindaprasirt, U. Rattanasak, C. Jaturapitakkul, Utilization of fly ash blends from pulverized coal and fluidized bed combustions in geopolymeric materials, Cem. Con. Comp. 33 (2011), pp 55-60

16. ASRO, SR EN 450-1:2012 Fly ash for concrete. Definition, specifications and conformity criteria, Romanian Standards Association, Bucharest, Romania (2012)

17. ASRO, SR EN 197-1:2011 Cement. Composition, specification and conformity criteria for common cements, Romanian Standards Association, Bucharest, Romania (2011)

18. A. Lăzărescu, Mix design and testing of the preliminary fly ash-based geopolymer mixes, $\mathrm{PhD}$. Report, Technical Univeristy of Cluj-Napoca, Romania (2017)

19. J. Davidovits, Properties of geopolymer cements, Alkaline Cements and Concretes, Kiew, Ukraine (1994), pp. 131-149

20. A. Lăzărescu, H. Szilagyi, C. Baeră, A. Ioani, The Effect of Alkaline Activators Ratio on the Compressive Strength of Fly Ash-Based Geopolymer Paste, IOP Conf. Series: Materials Science and Engineering (2017)

21. F. Pacheco-Torgal, J. Castro-Gomez, S. Jalali, Alkaliactivated binders: A review. Part 1. Historical background terminology, reaction mechanisms and hydration products, J. Constr. Build. Mater. 22 (2008), pp. 1305-1314

22. K. Somna, C. Jaturapitakkul, P. Kajitvichyanukul, P. Chindaprasirt, NaOH-activated ground fly ash geopolymer cured at ambient temperature, Fuel 90 (2011), pp. 2118-2124

23. B.V. Rangan, Mix design and production of fly ash based geopolymer concrete, Ind. Conc. J. 82 (2008), pp 7-15

24. V.M. Malhotra, Introduction: Sustainable Structures in the $21^{\text {st }}$ Century, ACI Concr. Int. 23 (2001) 3, pp. 57-63

25. V.F. Barbosa, K.J. Mackenzie, C. Thumaturgo, Synthesis and characterisation of materials based on inorganic polymers of alumina and silica sodium polysialate polymers, Int. J. 2 (2000), pp. 309-317 
26. R. Anuradha, V. Sreevidya, R. Venekatasubramani, B.V. Rangan, Modified guidelines for geopolymer concrete mix design using Indian standard, AJCE 13 (2012) 3, pp. 353-364

27.B.V. Rangan, Geopolymer Concrete for Environmental Protection, Indian Concr. J., Special Issue - Future Concrete (2014), pp. 41-59

28. M. Sofi, J.S.J. van Deventer, P.A. Mendis, G.C. Lukey, Engineering Properties of Inorganic Polymer Concretes (IPCs), Cem. Concr. Res. 37 (2007) 2, pp. 251-257

29. H. Xu, J.S.J. van Deventer, The Geopolymerisation of Alumino-Silicate Minerals, Int. J. Miner. Process. 59 (2000) 3, pp. 247-266

30. ASTM, Standard Test Methods for Sampling and Testing Fly Ash or Natural Pozzolans for Use in Portland-Cement Concrete, ASTM C618, in Annual Book of ASTM Standard, West Conshohcken, USA (2004)

31. A.M. Fernandez-Jimenez, A. Palomo, Characterisation of Fly Ash. Potential Reactivity as Alkaline Cements, Fuel 82 (2003), pp. 2259-2265

32. C.-H. Huang, S.-K. Lin, C.-S. Chang, H.-J. Chen, Mix proportions and mechanical properties of concrete containing very high-volume of Class F fly ash, Constr. Build. Mater. 46 (2013), pp. 71-78

33. P. Chindaprasrt, C. Jaturapitakkul, T. Sinsiri, Effect of Fly Ash Fineness on Compressive Strength and Pore Size of Blended Cement Paste, Cement Concrete Comp. 27 (2005), pp. 425-428

34. A.-T. Mircea, Study upon ApplyingvMulti-Criteria Analysis to the Selection of Building Materials, $28^{\text {th }}$ International Business-Information-ManagementAssociation Conference, Seville, Spain 1-4 (2016), pp. 1354-1360

35. O. Corbu, A.M. Ioani, M.M. Al Bakri Abdullah, V. Meiță, H. Szilagyi, A.V. Sandu, The Pozzolanic Activity Level of Powder Waste Glass in Coomparisons With Other Powders, International Conference on Innovative Research ICIR EUROINVENT 2015660 (2015), pp. 237-243 